\title{
Approach to Strengthen Community Participation of Teaching-Learning Process in Primary School
}

\author{
Suprapto', Mohammad Viktor Farid Hakim² \\ DOI: 10.35445/alishlah.v13i2. 604
}

\section{Article Info \\ Keywords: \\ Approach; \\ Community \\ Participation; \\ Primary School}

Kata kunci:

Pendekatan;

Partisipasi Komunitas;

Sekolah Dasar

\begin{abstract}
The purpose of the study was to get the approach of community participation in Islamic Primary School North Ampenan. The participation of all parties greatly influences the success of the implementation of teaching and learning as an educational process in schools. The research method was used qualitatively. The data were collected through observation, interviews, and questionnaires. The participants involved were principals, teachers, parents, and school committees. Data analysis techniques consist of data reduction, data presentation, and concluding. While checking the validity of the data consists of credibility, dependability, confirmability, and transferability. The study results indicate that the approach required is centralized participation which refers to lifelong learning and integrated services. Various activities or community participation actions greatly influence implementing the education process at SDI Ampenan Utara, Mataram. The research implications are seen in the development of various community participation actions in building school quality.
\end{abstract}

\begin{abstract}
Abstrak
Penelitian ini bertujuan untuk mendapatkan pendekatan partisipasi komunitas di Sekolah Dasar Islam Ampenan Utara Mataram. Partisipasi semua pihak sangat mempengaruhi keberhasilan pelaksanaan pengajaran dan pembelajaran sebagai proses pendidikan di sekolah. Metode penelitian menggunakan kualitatif. Adapun data dikumpulkan melalui observasi, wawancara, dan kuesioner. Partisipan yang terlibat adalah kepala sekolah, guru, orang tua, dan komite sekolah. Teknik analisis data terdiri dari reduksi data, penyajian data, dan penarikan kesimpulan. Sedangkan pengecekan keabsahan data terdiri dari kredibilitas, dependabilitas, konfirmabilitas, dan transferabilitas. Hasil penelitian menunjukkan bahwa pendekatan yang dibutuhkan adalah partisipasi terpusat yang merujuk pada konsep pembelajaran sepanjang hidup dan pelayanan terpadu. Berbagai kegiatan ataupun tindakan partisipasi komunitas memberikan pangaruh yang cukup baik terhadap penyelenggaraan proses pendidikan di SDI Ampenan Utara, Mataram. Implikasi penelitian terlihat pada pengembangan berbagai tindakan partisipasi komunitas dalam membangun kualitas sekolah.
\end{abstract}

\footnotetext{
${ }^{1}$ UIN Mataram, Mataram, Indonesia Email: viktorfaridhakim@gmail.com 2 UIN Mataram, Mataram, Indonesia Email: viktorfaridhakim@gmail.com
} 


\section{INTRODUCTION}

The success of implementing education in elementary schools is influenced by all the academic communities involved in learning and teaching activities at school. However, the role of the community also has a considerable influence. The community can take responsibility indirectly for the implementation of education. The responsibility is to improve the quality of governance with various policies and in schools, parents, and community participation (Arifin, 2016). Especially during the Covid-19 pandemic that has hit the world from 2020, it has affected implementing education. Parents must also actively participate in assisting their children to study at home. The current community participation approach will help achieve learning objectives. It means that education takes place in schools and within the family, community, and society. Therefore, building and developing partnerships between schools, parents, and the community is significant. There are various reasons to support the idea that community participation contributes to achieving this goalone of the parameters determining the fate of education in society. If there is advanced education, it is almost certain that one of the success factors is maximum community involvement and participation. Vice versa, if there is education that has a miserable fate, one of the causes could be that the community is reluctant to support it (Asha, 2019; Jabeen, Haq, \& Hussain, 2018).

The concept of community involvement in school administration requires an understanding of various related parties, especially regarding their position and the benefits (Jabeen et al., 2018). Communities can play a variety of roles in the provision and management of education and the learning process. Community participation can promote education and quality (Aref, 2010; Parji \& Prasetya, 2020). Community involvement in education is felt to be very necessary, and now it is hoped that it is not only a form of concept and discourse but more than action in the field (Siswanto, 2013). Community participation is still minimal, such as participating in being a community member at implementing development programs (Sada, 2017). Therefore, special attention is needed to develop education in the present and the future (Subianto, 2013; Godfrey, 2016). The process of participating community and parents of students in the school environment is for making inputs, decisions, and gathering supports that require preparation so that national development such as education can be encouraged and improve the quality of schools (Kusumaningrum, Ulfatin, Maisyaroh, Triwiyanto, \& Gunawan, 2017).

This condition is also very important for the North Ampenan Islamic Elementary School in Mataram. Schools need community involvement in achieving educational goals. They work independently in providing education but require community participation to support various problems that arise in the implementation of teaching and learning, fulfillment of school facilities and infrastructure, financial needs to support activities at school or curriculum development that must be designed to meet community needs. And the world of industry. However, the study is different from previous research. It focuses on the approach to strengthen community participation. Thus, the purpose of the study is to know the approach to strengthen community participation in the teaching and learning process.

\section{METHODS}

This study used a qualitative research approach. So, in this study, identifying the need for an approach to strengthening community participation in the education process was carried out at Islamic Primary School North Ampenan Mataram. The participants involved were principals, teachers, parents, and school committees $(\mathrm{N}=10)$. Data were collected through observation, interviews, and surveys by distributing questionnaires. Observations are made by visiting schools and observing activities that involve community participation. Interviews were addressed to all participants as supporting data from the results of observational data analysis. Meanwhile, questionnaires were also distributed to participants. The elements used in designing questionnaire questions include; 
1. Schools as community centers: lifelong learning and integrated services

2. Schools conduct sociological investigations: environmental involvement for educational development needs

3. Entrepreneurship-based schools: develop entrepreneurship that can develop schools and graduates.

Data analysis techniques consist of data reduction, data presentation, and concluding. While checking the validity of the data consists of credibility, dependability, confirmability, and transferability.

\section{FINDINGS AND DISCUSSION}

The result of data analysis presented the concept of an approach to strengthening community participation in school is as a community center. The school creates lifelong learning and integrated learning. The following is the data found;

\begin{tabular}{|c|c|c|c|}
\hline Approach & Aspects & Action & Percentage \\
\hline \multirow[t]{10}{*}{$\begin{array}{l}\text { Community } \\
\text { Centre }\end{array}$} & Lifelong learning & $\begin{array}{l}\text { 1. Utilization of human resources in mutualism } \\
\text { Community }\end{array}$ & $70 \%$ \\
\hline & & 2. Interest in sending their children to school & $90 \%$ \\
\hline & Integrated & 1. Provision and or use of shared facilities & $80 \%$ \\
\hline & services & 2. Curriculum update & $80 \%$ \\
\hline & & 3. Textbook repair & $70 \%$ \\
\hline & & 4. Teaching method & $80 \%$ \\
\hline & & $\begin{array}{l}\text { 5. Effective teacher education and provision of } \\
\text { material facilities in schools, }\end{array}$ & $90 \%$ \\
\hline & & 6. Progressive evaluation method, & $80 \%$ \\
\hline & & $\begin{array}{l}\text { 7. Democratize and humanize school } \\
\text { administration and }\end{array}$ & $90 \%$ \\
\hline & & 8. Supervision, provision of resources and culture & $80 \%$ \\
\hline
\end{tabular}

Education exists because of the community's needs, while the progress or decline of the community is influenced and even determined by the education system (Ali \& Abdullah, 2019). The approach of school community participation in the implementation of elementary school education programs in Mataram City is the school as a community center. It means that the school has instilled the concept of cooperation with all parties who need to be involved in building the school because the development of education can be done by schools alone, but through cooperation, achieving educational goals can be achieved.

The results of interviews and observations have strengthened the data findings. The school already has a pretty good way of increasing the community to actively participate or be active in the various programs that have been launched. Thus, the implementation of education in schools has good quality and can meet the community's wishes for the implementation of education in schools. In addition, the community involved is not only parents or school committees. Other stakeholders are also constantly involved in implementing various strengthening programs to improve the quality of education in schools.

Therefore, the school committee's community participation approach is in harmony with the forms of participation that have been developed in schools (Ali \& Abdullah, 2019). This means that improving the quality of primary education raises many issues such as curriculum renewal, improvement of textbooks, better teaching methods, effective teacher education and provision of material facilities in schools, progressive evaluation methods, democratization, and humanizing school administration and supervision resources-rich and cultural. Various programs of cocurricular activities are healthy interactions between schools and communities, improvement of single teacher schools etc. The problems of wastage, stagnation, dropout and increased education are intertwined. The reasons for the effectiveness of Schooling, Community Participation, and 
Classroom Teaching in primary schools provide us with many valuable insights into various aspects of the problem (Panigrahi, 2013). Community participation in education infrastructure creates opportunities for decision making, resource utilization and allocation and management.

Lewis Ngesu, Anastasia Gakuru, Samson Okuro Gunga, Christine Kahigi suggested that community participation can also refer to parents' interest in their children's schooling by enrolling them in pre-school, providing school needs, their basic needs such as open days and gift-giving days. Talk to the teacher about the child's progress. In short, community participation requires responsibility by the community and its members to do the best for each other with full knowledge and understanding that if the community is prosperous, its members will share that prosperity and society cannot prosper without the full cooperation of the community (Ngesu, Gakuru, Gunga, \& Kahigi, 2013).

All programs reveal that the level of education fosters community participation with different intensities (Wedam, Quansah, \& Debrah, 2015; Kaluge, 2018). This is in line with the often voiced view that the focus is on increasing resources (Pradhan et al., 2014). In addition, community involvement usually ensures more equitable use of school resources. It increases transparency in financial transactions, thereby encouraging potential donors to improve school performance and ensure quality education delivery (Sofoluwe \& Akinsolu, 2015). Therefore, the community is required to participate in government efforts to develop programs such as the construction of classrooms in environment-based secondary schools to ensure that all students who pass exams and are supposed to enter secondary school do not miss this opportunity (Kambuga, 2013).

From various previous research studies, community participation in education is the main thing. This study highlights how the concept of strengthening community participation at Islamic Primary School Ampenan Utara Mataram is related to the theoretical concepts implemented from various school programs that have been carried out so that different research results are generated by developing the concept of community participation according to the needs of each school and region. Community mobilization is very important as it creates awareness among stakeholders; people become aware of material resources, leadership, technical expertise, and the kind of help they may need from outside. Therefore, the community must be politically mobilized through education and training about the importance of their project and making them feel that the project belongs to them. In this case, the community can make decisions about matters relating to their social development. The involvement of people in the sustainable development of environmentally-based schools gives them the power to make decisions related to their social development, where they enjoy awareness of all processes related to their socio-economic needs and productivity.

\section{CONCLUSION}

Education is a shared responsibility between the government (madrasah-schools), families and society as a community. This implies that parents and the community have a responsibility to participate, think about, and provide assistance in implementing education in schools. The study results conclude that the approach to strengthening community participation is to support a centered teaching and learning process. So, community empowerment in education is essential for the implementation of good madrasa education. Various forms of cooperation that can be developed with various institutions are (1) the provision and or use of shared facilities and (2) the mutual use of human resources. Various facilities that are not owned by madrasas may exist and are owned by certain institutions that allow them to be used together-implementation of activities to improve students' abilities. For example, madrasahs wishing to improve students' understanding and ability about health can collaborate in utilizing various facilities, including human resource facilities.

This research has implications for developing various activities related to community participation at Islamic Primary School Ampenan Utara. Strengthening community participation has been realized to support the implementation of teaching and learning. However, in this study, 
the strengthening of community participation was focused on various programs or activities carried out at Islamic Primary School Ampenan Utara, which were exposed to the concept of the theory of form or community participation used. This is because the understanding of community participation in the implementation of education is oriented towards community support for various activities carried out in schools and how schools can build the concept of community participation by the implemented theory by strengthening the quality of education.

\section{REFERENCES}

Ali, L., \& Abdullah, T. (2019). Community Participation in The Implementation of Education. Jurnal Kepemimpinan Pendidikan, 2(2), 333-354.

Aref, A. (2010). Community Participation for Educational Planning and Development. Nature and Science, 8(9), 1-4.

Arifin, Z. (2016). Community Participation in Education Management For Improving Quality Education. DIA, Jurnal Administrasi Publik, 14(2), 179-196.

Asha, L. (2019). Dewan Pendidikan Dalam Meningkatkan Mutu Pendidikan Di Kabupaten Rejang Lebong). Tadbir: Jurnal Studi Manajemen Pendidikan, 3(1), 38-56. https://doi.org/http://dx.doi.org/10.29240/jsmp.v3i1.739

Godfrey, S. M. (2016). Challenges Impacting Community Participation and Their Effect on Teaching and Learning: a Case Study of Rural Areas. European Scientific Journal, ESJ, 12(25), 345. https://doi.org/10.19044/esj.2016.v12n25p345

Jabeen, S., Haq, M. N. U., \& Hussain, I. (2018). Community Participation in Socio-Economic Development through Secondary Education in one of the Remotest Regions of Pakistan. European Online Journal of Natural and Social Sciences, 7(4), 663-680.

Kaluge, L. (2018). The Evaluation of Community Participation in Basic Education Management. In Annual Conference on Social Sciences and Humanities (pp. 170-178).

Kambuga, Y. (2013). The Role of Community Participation in the Ongoing Construction of Ward Based Secondary Schools: Lessons of Tanzania. International Journal of Education and Research, 1(7), 1-10.

Kusumaningrum, D. E., Ulfatin, N., Maisyaroh, Triwiyanto, T., \& Gunawan, I. (2017). Community Participation in Improving Education Quality. Advances in Economics, Business and Management Research, 45, 39-47.

Ngesu, L., Gakuru, A., Gunga, S. O., \& Kahigi, C. (2013). Factors Hindering Community Participation In The Development of Ecde Centres. International Journal of Education and Research, 1(7), $1-6$.

PANIGRAHI, M. R. (2013). School Effectiveness at Primary Level Levels of Education In Relation to Community Participation. International Journal on New Trends in Education and Their Implications, 4(2), 60-74.

Parji, F., \& Prasetya, A. (2020). Community participation in developing educational quality for primary school in Madiun City. Utopía y Praxis Latinoamericana, 25(6), 189-196.

Pradhan, M., Suryadarma, D., Beatty, A., Wong, M., Gaduh, A., Alisjahbana, A., \& Artha, R. P. (2014). Improving educational quality through enhancing community participation: Results from a randomized field experiment in Indonesia. American Economic Journal: Applied Economics, 6(2), 105-126. https://doi.org/10.1257/app.6.2.105

Sada, H. J. (2017). Peran Masyarakat Dalam Pendidikan perspektif Pendidikan Islam. AlTadzkiyyah: Jurnal Pendidikan Islam, 8(1), 117. https://doi.org/10.24042/atjpi.v8i1.2120

Siswanto. (2013). Partisipasi Masyarakat Dalam Pendidikan Islam (Peran Komite Sekolah/Madrasah). Insania, 18(1), Insania.

SOFOLUWE, A. O., \& AKINSOLU, A. O. (2015). Community Participation in Quality Assurance (CPQA): A Catalyst in Enhancing Quality Basic Education Service Delivery in Nigeria. Journal of Education and Practice, 6(7), 12-19.

Subianto, J. (2013). Peran Keluarga, Sekolah, dan Masyarakat Dalam Pembentukan Karakter Berkualitas. Edukasia: Jurnal Penelitian Pendidikan Islam, 8(2), 331-354.

Wedam, E., Quansah, J. Y. D., \& Debrah, I. A. (2015). Community Participation in Educational Infrastructure Development and Management in Ghana. Education, 5(5), 129-141. 